\title{
Cytokinin induces the development of gabirobeira root cuttings
}

\section{Lasara Kamila Ferreira de Souza ${ }^{1}$ Ald Alejandro Hurtado-Salazar $^{2 *}$ (i) Francielly Rodrigues Gomes $^{1}$ (D) Laísse Danielle Pereira ${ }^{1}$ Diego Ismael Rocha ${ }^{1}$ Danielle Fabíola Pereira da Silva ${ }^{1}$ (iD}

${ }^{1}$ Universidade Federal de Jataí (UFJ), Jataí, GO, Brasil.

${ }^{2}$ Universidad de Caldas, 170004, Manizales, Caldas, Colombia. E-mail: alhuza@gmail.com. "Corresponding author.

ABSTRACT: The gabirobeira is a species native to the Brazilian Cerrado with potential for use in cropping systems. This study evaluated the effect of the cytokinin 6-benzylaminopurine (BAP) on root cuttings of gabirobeira (Campomanesia adamantium). The plant material was obtained from gabirobeira progenies of one and two-years-old. The cuttings were segmented in $5 \mathrm{~cm}$ length and 1.90 to $3.22 \mathrm{~mm}$ diameter, immersed in the following BAP concentrations: 0.0; 1.0; 2.0 and $4.0 \mathrm{mg} \mathrm{L} L^{-1}$ for 15 seconds and planted in trays containing the substrate Bioplant ${ }^{\mathbb{R}}$. A complete randomized experimental design was adopted in a factorial scheme $2 x 4$, (cuttings age $x$ BAP concentrations) with fifteen replicates per treatment. After 140 days the number of cuttings with shoots, number of shoots, number of leaves, and diameter of the main root were evaluated. The better development of the cuttings was observed on progenies of two-years-old. The lowest cytokinin concentrations promoted the better emission and number of shoots of the progenies from both ages.

Key words: Campomanesia adamantium, plant growth regulator, shoots, native species.

Citocininas induzem o desenvolvimento de estacas de raiz de gabirobeira

RESUMO: A gabirobeira é uma espécie nativa do Cerrado brasileiro com potencial para uso em sistemas de cultivo. O objetivo deste estudo foi avaliar o efeito da 6-benzilaminopurina (BAP) em estacas radiculares de progênies de Gabirobeira (Campomanesia adamantium). As estacas radiculares foram obtidas de progênies de Gabirobeira de um e dois anos de idade. Estes foram segmentados em $5 \mathrm{~cm}$ de comprimento e apresentavam entre 1,90 a 3,22 mm de diâmetro, imersos nas concentrações: 0.0; 1.0; 2.0 e $4.0 \mathrm{mg} \mathrm{L} \mathrm{L}^{-1}$ de BAP por 15 segundos e plantados em bandejas contendo Bioplant ${ }^{\circledR}$. O delineamento experimental foi o inteiramente casualizado, em esquema fatorial $2 x 4$ (idades das estacas $x$ concentrações de BAP), com quinze repetições por tratamento. Após 140 dias, foram avaliados o número de estacas com brotações, número de brotações, número de folhas e diâmetro da raiz principal. Estacas de raizes de progênies de dois anos de idade apresentaram melhor desenvolvimento. Menores concentrações de citocinina trouxeram melhores resultados de emissão e número de brotações das progênies de ambas as idades.

Palavras-chave: Campomanesia adamantium, regulador de crescimento, brotos, espécies nativas.

The species from the genus Campomanesia (Myrtaceae) are native to the Brazilian Cerrado and some parts of Argentina and Paraguay, they have good market acceptance due to their specifics characteristics, such as sweet flavor and pleasant smell. This species produces a high number of fruits per plant and has great genetic variability that can be used on cultivar development. Its fruits can be consumed in natura or processed to compose desserts, ice-creams or juices, and this diversity of use gives to Campomanesia plants a high economic potential who needs to be better exploited and characterized to its probable domestication (DAMIANI et al., 2016;
ARAÚJO \& SOUZA, 2018; ZUNTINI et al., 2017; ARANCON et al., 2019).

The predatory exploitation combined with the expansion of new agricultural frontiers causes genetic erosion and contribute to environmental degradation, making it difficult to continue the evolutionary process and implementation of initiatives aiming species pre-breeding. Thus, actions aiming to plant propagation may allow the expansion of the genetic basis, conservation and reproduction of plants (ALMEIDA et al., 2019).

The species from the genus Campomanesia are allogamous and usually are propagated by seeds; 
however, it presents high genetic variability by sexual propagation and has recalcitrant seeds that do not tolerate storage, which makes the uniform reproduction of progenies difficult (EMER et al., 2018a). An alternative is the employ of vegetative propagation techniques, it includes air layering (TELEGINSKI et al., 2018), cuttings (MARTINS et al., 2015; EMER et al., 2016; EMER et al., 2018b) or in vitro (ROSSATO et al., 2015; GOELZER et al., 2019; ROSSATO et al., 2019; MACHADO et al., 2020), always associated with plant growth regulators.

Therefore, vegetative propagation through root cuttings is one of the alternatives that allow the anticipation of the reproductive stage, reduces the juvenile period of the plants and ensures that their characteristics will be maintained (BIAZATTI et al., 2018). Few researches are using in vivo propagation of Campomanesia in the literature, but its use may be an alternative for the production of clonal nursery trees since great results have been obtained for other species and contributed to fast reproductions of new progenies (KOUAKOU et al., 2016). Besides, the use of cytokinin may be helpful to induce adventitious shoots when used exogenously favoring the development of vegetative organs (AZIZ \& ALTAWEEL, 2019).

It is known that the age of the cuttings influences the propagation due to the variation in the hormonal concentration, in the carbohydrate reserve and the degree of lignification of the vegetative material (ROSA et al., 2017), thus, this study aimed to evaluate the effect of the cytokinin 6-Benzylaminopurine (BAP) in root cuttings of $C$. adamantium obtained from progenies of one and two-years-old.

The vegetative material of $C$. adamantium was obtained from progenies of 1 and 2-years-old propagated by seeds collected in the municipality of Jataí - GO. The branches were collected in the morning and standardized with $5 \mathrm{~cm}$ length and a diameter ranging from $1.903 .22 \mathrm{~mm}$. After the preparation of the solution, the cuttings were immersed in 6-benzylaminopurine (BAP [Sigma Aldrich]) solution at the concentrations: $0 ; 1.0 ; 2.0$ and $4 \mathrm{mg} \mathrm{L}^{-1}$ diluted in $\mathrm{NaOH}\left(6 \mathrm{~mol} \mathrm{~L}^{-1}\right)$ for 15 seconds. In the control, the cuttings were treated with distilled water. Subsequently, the planting was carried out in polypropylene tubes $\left(55 \mathrm{~cm}^{3}\right)$ containing Bioplant ${ }^{\mathbb{B}}$, which is composed of pine bark, manure, sawdust, coconut fiber, vermiculite, rice husk, ashes, gypsum, calcium carbonate, magnesium, magnesium thermophosphate $\left(\right.$ yoorin $^{\circledR}$ ), and additives (fertilizers). During the experimental period, intermittent mist irrigation was programmed to be activated for one minute every hour for 12 hours (6:00 am - 6:00 pm). The cuttings were kept on a greenhouse covered with polyethylene tarp and anti-aphid screen at the Federal University of Jataí - GO $\left(17.8828^{\circ} \mathrm{S}, 51.7264^{\circ} \mathrm{W}\right)$.

After 140 days the cuttings were evaluated for the number of cuttings with adventitial shoots (NCS), obtained by direct counting, the number of shoots (NS), the length of shoots (LS), the number of leaves (NL), the length of leaves (LL) and the diameter of the main root (DMR), measured with a digital caliper and given in $\mathrm{mm}$.

The experimental design was completely randomized in a factorial scheme $2 \times 4$, (two ages of root cuttings $x$ four concentrations of BAP) with fifteen replicates per treatment, in which each tube was considered an experimental unit.

The data were subjected to analysis of variance, and the effects of the concentrations were tested and adjusted in regression equations. The models were chosen based on the significance of the regression coefficients using the t-test $(p<0.05)$, on the coefficient of determination $\left(\mathrm{R}^{2}\right)$ and on the potential to explain the biological phenomenon. The averages from the BAP concentrations were compared by the Duncan test $(p<0.05)$. The data analysis was performed with the aid of the statistical program Sas (STATISTICAL ANALYSIS SYSTEM, 2002).

Results observed for the number of cuttings with adventitial shoots (NCS) for the progenies of one and two-years-old had a quadratic adjustment. The two-year-old root cuttings emitted 0.93 shoots at the concentration of $0.15 \mathrm{mg} \mathrm{L}^{-1}$, and the one-year-old progenies emitted 0.21 shoots at $1.0 \mathrm{mg} \mathrm{L}^{-1}$ of BAP (Figure 1A). The increase in BAP concentrations is responsible for the reduction in the number and size of the plant structures since high concentrations can repress vegetative growth (MEGHWAL et al., 2010), this behavior could be observed in figure 2, in which the highest concentrations did not allow the development of the root cuttings.

The exogenous supplementation of lowest concentrations of BAP evidences its decisive impact on the growth regulation and the photosynthetic mechanism stabilization, modulating the responses according to its levels on the tissues (PREROSTOVA et al., 2018). The cytokinin (BAP) is responsible for breaking the apical dominance inducing the proliferation of axillary shoots, and when associated with other plant growth regulators it stimulates cell division and differentiation, transforming the cells into plant organs through morphogenesis (MÁXIMO et al., 2018).

The number of shoots on root cuttings from the progenies of both ages was adjusted by the 


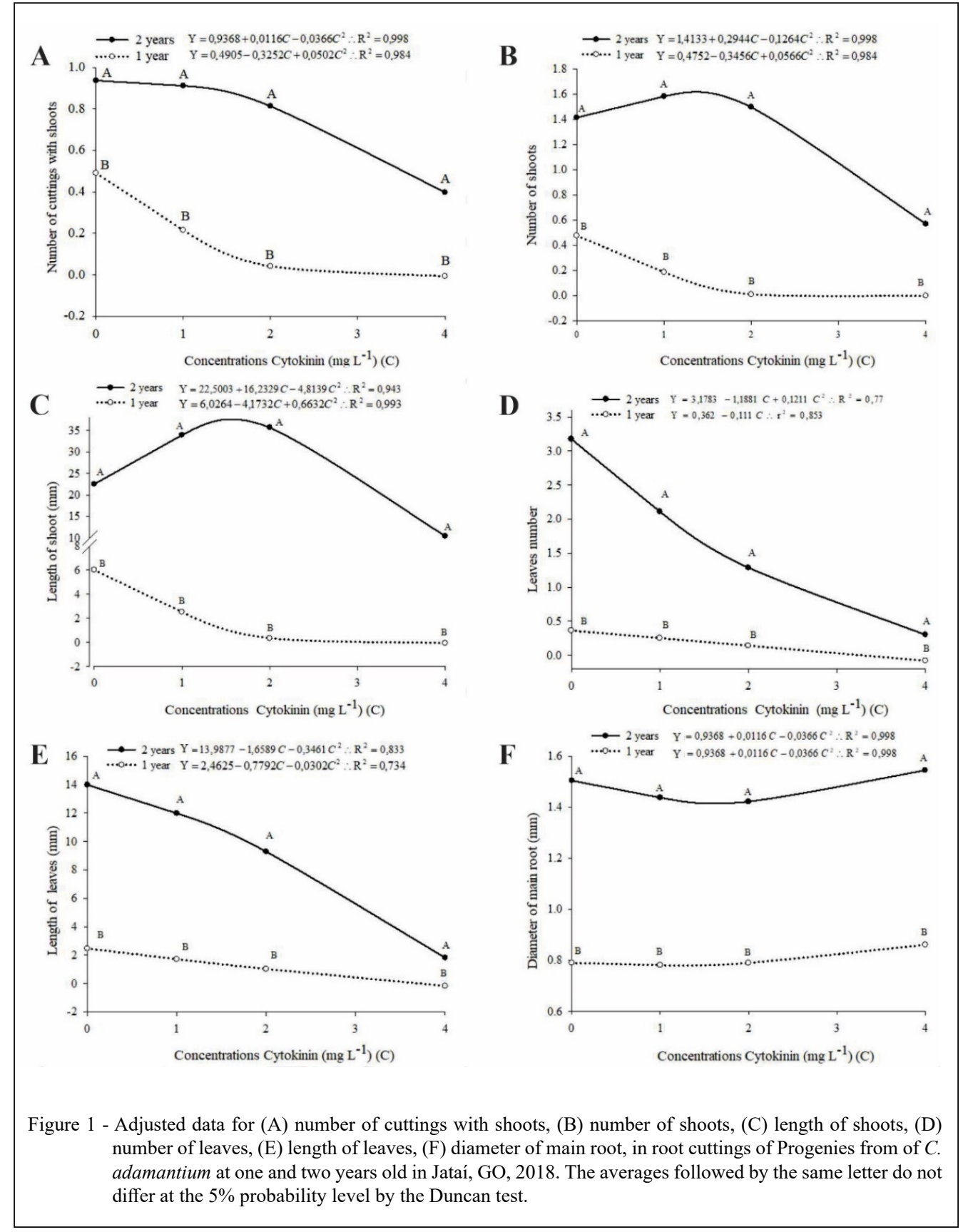

quadratic equation. The concentration of $1.68 \mathrm{mg} \mathrm{L}^{-1}$ promoted the maximum development of two-year-old progenies, which was 1.58 shoots. In one-year-old progenies, the concentration of $2.0 \mathrm{mg} \mathrm{L}^{-1}$ developed a total of 0.01 shoots. (Figure 1B). ROSSATO et al. (2015), evaluating the effect of the BAP on the multiplication and rooting of $C$. adamantium in vitro, reported that there were a great number of shoots in the absence of the plant growth regulator, probable due to endogenous levels of cytokinin on the vegetative material.

The length of shoots from $C$. adamantium root cuttings of one and two-years-old was adjusted by the quadratic model as a function of BAP concentrations. The maximum length of the shoots on two-years-old progenies was $36 \mathrm{~mm}$ at the concentration of $1.68 \mathrm{mg}$ $\mathrm{L}^{-1}$. The concentration of $2.0 \mathrm{mg} \mathrm{L}^{-1}$ promoted shoots with a minimum of $0.33 \mathrm{~mm}$ length in one-year-old

Ciência Rural, v.51, n.6, 2021. 


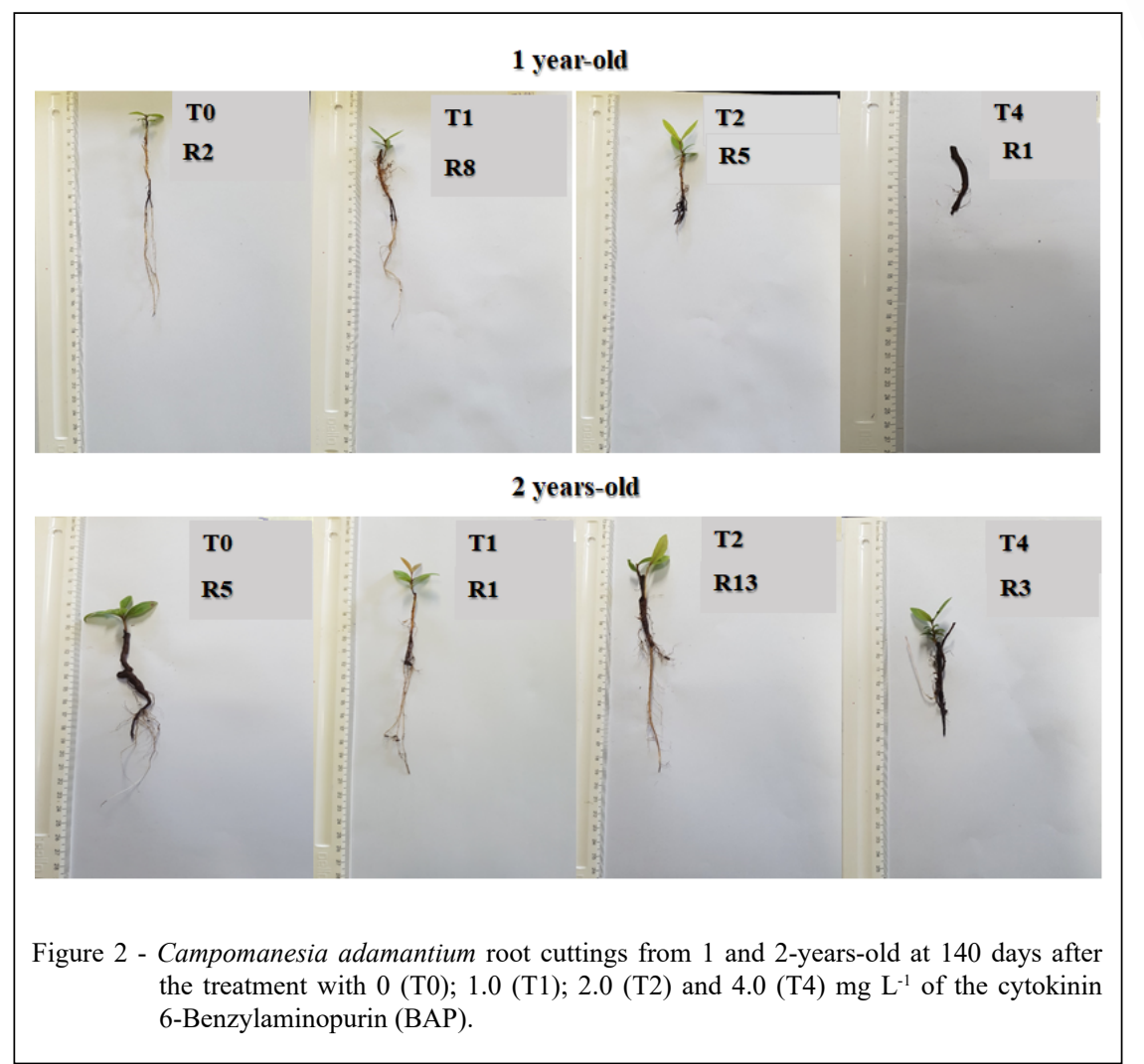

progenies (Figure 1C), indicating that the responses to the cytokinin varied according to the genetic potential of the species, which is a process widely controlled (CHENG et al., 2013).

The BAP plays an important role in the multiplication of axillary gems, modulating the size, the length, and the number of leaves. When supplemented exogenously, depending on the concentration, it may cause a decrease in the growth of structures for being biologically active (KIEBER \& SCHALLER, 2018). Similar results were obtained by GOELZER et al. (2019), in which the increase of BAP concentrations led to a reduction in the length of the shoots of $C$. adamantium explants grown in the murashige and skoog medium (MS).

The number of leaves from one-year-old root cuttings had a linear adjustment and the twoyears-old progenies had a quadratic adjustment. The cuttings from both ages produced a higher number of leaves in the absence of the cytokinin supplementation. At the concentration of $4.0 \mathrm{mg} \mathrm{L}^{-1}$, there was an emission of 0.36 leaves in progenies of two-years-old, and 0.14 leaves in progenies of oneyear-old (Figure 1D).
The number of leaves is extremely important for the development of the cuttings, due to the accomplishment of photosynthesis with the availability of photoassimilates or by the essential dynamics between the shoots and the root system (PEREIRA et al., 2017). ASMAR et al. (2012), evaluating BAP concentrations on Lippia alba in vitro propagation observed a decrease in the number of leaves at higher concentrations of cytokinin, BHALLA et al. (2009), also reported that the addition of BAP on the MS in the propagation of Hibiscus Rosa-sinensis led to a decrease in the number of leaves.

The length of leaves from progenies of one and two-years-old of $C$. adamantium supplemented with BAP had a quadratic adjustment. The absence of exogenous BAP supplementation provided a greater length on progenies from both ages; however, at the concentration $2.0 \mathrm{mg} \mathrm{L}^{-1}$, the length of leaves from twoyears-old progenies was $0.78 \mathrm{~mm}$, and at the concentration $1.0 \mathrm{mg} \mathrm{L}^{-1}$ on one-year-old progenies, the leaves presented $1.65 \mathrm{~mm}$ length (Figure 1E). TIBERTI et al. (2015), observed that Rubus idaeus root cuttings treated with different concentrations of BAP presented a reduction in the size of its structures as the concentrations 
increased and were bigger at the absence of plant growth regulators, probably caused by phytotoxicity.

The diameter of the main root of progenies

from $C$. adamantium with one and two-years-old supplemented at different concentrations of the cytokinin 6-Benzylaminopurine had a quadratic adjustment. The diameter of the roots was not influenced by the exogenous BAP supplementation in cuttings of progenies of one and two-years-old and they presented similar behavior (Figure 1F).

The consistency in the root diameter demonstrated that cytokinin does not act in the modulation and regulation of this structure (KIEBER \& SCHALLER, 2018). Commonly, the exogenous supplementation of cytokinin induces root diameter due to the swelling in the root elongation zone (BERTELL \& ELIASSON, 1992).

Concerning the evaluated parameters of C. adamantium, the progenies of two-years-old had a greater development, which suggested the potential of this material for its conservation and reproduction. The use of cytokinin at reduced concentrations can favor the growth and development processes of gabirobeira root cuttings, and the use of this plant growth regulator can help in the process of rapid mass propagation of true-to-type vegetative material of $C$. adamantium.

\section{ACKNOWLEDGEMENTS}

The authors thank Conselho Nacional de Desenvolvimento Científico e Tecnológico (CNPq), Coordenação de Pesquisa e Inovação (COPI) Universidade Federal de Jataí (UFJ) and Coordenação de Aperfeiçoamento de Pessoal de Nível Superior (CAPES), for the financial support.

\section{DECLARATION OF CONFLICT OF INTERESTS}

The authors declare no conflict of interest. The funding sponsors had no role in the design of the study; in the collection, analysis, or interpretation of data; in the writing of the manuscript, and in the decision to publish the results.

\section{AUTHORS' CONTRIBUTIONS}

Conceptualization and material collection: Souza LKF, Gomes FR, Pereira LD. Design of methodology and data acquisition: Souza LKF, Salazar AH, Silva DFP. Data analysis: Souza LKF, Salazar AH, Pereira LD. Writing and editing: Souza LKF. Review of the manuscript: Salazar AH, Rocha DI, Silva, DFP. Orientation: Silva DFP.

\section{REFERENCES}

ALMEIDA, G. Q. et al. Agronomic evaluation of a Hancornia speciosa germplasm collection from the Brazilian Cerrado. Crop
Breeding and Applied Biotechnology, v.19,p.8-14,2019.Available from: <http://dx.doi.org/10.1590/1984-70332019v19n1a02> Accessed: Nov. 21, 2019. doi: 10.1590/1984-70332019v19n1a02.

ARANCON, N. et al. The influence of vermicompost water extracts on growth of plants propagated by cuttings. Journal of Plant Nutrition, p.176-185. Available from: $<$ https://doi.org/10 .1080/01904167.2019.1659355>. Accessed: Nov 18, 2019. doi: $10.1080 / 01904167.2019 .1659355$.

ARAÚJO, E. F. L.; SOUZA, E. R. B. Phenology and reproduction of Campomanesia adamantium (Cambess.) O. Berg (Myrtaceae). Scientific Electronic Archives, v.11, p.166-175, 2018. Available from: <http:/www.seasinop.com.br/revista/index.php?journal=SE A\&page $=$ article \&op $=$ view \&path $\% 5 B \% 5 \mathrm{D}=414 \&$ path $\% 5 \mathrm{~B} \% 5 \mathrm{D}=$ pdf $>$. Accessed: Aug. 02, 2020.

ASMAR, S. A. et al. Concentrações de BAP sobre a proliferação in vitro de brotos de Lippia alba [(Mill.)N.E.Brown]. Revista Brasileira de Plantas Medicinais, v.14, p.149-153, 2012. Available from: <http://dx.doi.org/10.1590/S151605722012000500004>. Accessed: Aug. 09, 2020. doi: 10.1590/ S1516-05722012000500004.

AZIZ, R. A.; AL-TAWEEL, S. K. Effect of plant growth retadants on stevia (Stevia rebaudiana Bertoni) acclimatization produced in vitro. Plant Archives, v.19, p.1275-1284, 2019. Available from: $<$ http://plantarchives.org/PDF\%2019-1/1275-1284\%20(4837). pdf>. Accessed: Nov. 19, 2019.

BERTELL, G.; ELIASSON, L. Cytokinin effects on root growth and possible interactions with ethylene and indole-3-acetic acid. Physiologia Plantarum, v.84, p.255-261, 1992. Available from: $<$ https://doi.org/10.1111/j.1399-3054.1992.tb04662.x>. Accessed: Aug. 07, 2020. doi: 10.1111/j.1399-3054.1992.tb04662.x.

BHALLA, S. et al. Shoots Induction from Hibiscus Rosa-sinensis Nodal Explant Using N -benzylaminopurine (BAP). Research Journal of Agriculture and Biological Sciences, v.5, p.403-410, 2009. Available from: <http://www.aensiweb.net/AENSIWEB/ rjabs/rjabs/2009/403-410.pdf>. Accessed: Aug. 09, 2020.

BIAZATTI, M. A. et al. Multiplication of Cattley guava by different techniques and variability among genotypes in vigor and rooting. CERNE, v.24, p.379-386, 2018. Available from: < http:// dx.doi.org/10.1590/01047760201824042571>. Accessed: Sep. 7, 2019. doi: 10.1590/01047760201824042571.

CHENG, Z. J. et al. Pattern of auxin and cytokinin responses for shoot meristem induction results from the regulation of cytokinin biosynthesis by auxin response factor. Plant physiology, v.161, p.240-251, 2013. Available from: <https://doi.org/10.1104/ pp.112.203166>. Accessed: Oct. 29, 2019. doi: 10.1104/ pp. 112.203166 .

DAMIANI, R. C. et al. Seed origin, storage conditions, and gibberellic acid on in vitro germination of Campomanesia adamantium (Cambess.) O. Berg, African Journal of Biotechnology, v.15, p.1731-1737, 2016. Available from: <http:// dx.doi.org/10.5897/AJB2016.15277>. Accessed: Aug. 02, 2020. doi: $10.5897 /$ AJB2016.15277.

EMER, A. A. et al. Cutting from Campomanesia aurea O. Berg (Myrtaceae): The collection time of propagules and the effects of auxin. Revista Brasileira de Ciências Agrárias, v.13, p.17, 2018b. Available from: <https://doi.org/10.5039/agraria. 
v13i1a5494>. Accessed: Aug. 01, 2020. doi: 10.5039/agraria. v13i1a5494.

EMER, A. A. et al. Influence of indolebutyric acid in the rooting of Campomanesia aurea semihardwood cuttings. Ornamental Horticulture, v.22, p.94-100, 2016. Available from: <http:// dx.doi.org/10.14295/oh.v22i1.855>. Accessed: Aug. 01, 2020. doi: 10.14295/oh.v22i1.855.

EMER, A. A. et al. The physicochemical properties of fruits and seed germination of Campomanesia aurea O. Berg. Acta Scientiarum Biological Sciences, v.40: e35007, $2018 \mathrm{a}$. Available from: <https://doi.org/10.4025/actascibiolsci. v40i1.35007>. Accessed: Sep. 22, 2019. doi: 10.4025/ actascibiolsci.v40i1.35007.

GOELZER, A. et al. Reguladores de crescimento na multiplicação in vitro de Campomanesia adamantium (Cambess.) O. Berg (Myrtaceae). Brazilian Applied Science Review, v.3, p. 12801291, 2019. Available from: <http://dx.doi.org/10.34115/ basrv3n4-007>. Accessed: Aug. 01, 2020. doi: 10.34115/ basrv3n4-007.

KOUAKOU, K. L. et al. Propagation of Garcinia kola (Heckel) by stem and root cuttings. Silva Fennica, v.50 p.1-17, 2016. Available from: <http://dx.doi.org/10.14214/sf.1588>. Accessed: Oct. 12, 2019. doi: 10.14214/sf.1588.

MACHADO, J. S. et al. Micropropagation of Campomanesia xanthocarpa O. Berg (Myrtaceae), a medicinal tree from the Brazilian Atlantic Forest. Trees, v.34, p.791-799, 2020. Available from: <https://doi.org/10.1007/s00468-020-01958-z>. Accessed: Aug. 01, 2020. doi: 10.1007/s00468-020-01958-z.

MARTINS, W. A. et al. Estaquia e concentração de reguladores vegetais no enraizamento de Campomanesia adamantium. Revista de Ciências Agrárias, v.38, p.58-64, 2015. Available from: <http://www.scielo.mec.pt/pdf/rca/v38n1/v38n1a09.pdf >. Accessed: Aug. 01, 2020

MÁXIMO, W. P. F. et al. In vitro multiplication of eucalyptus hybrid via temporary immersion bioreactor: culture media and cytokinin effects. Crop Breeding and Applied Biotechnology, v.18, p.131-138, 2018. Available from: <http://dx.doi. org/10.1590/1984-70332018v18n2a19>. Accessed: Oct. 22, 2019. doi: 10.1590/1984-70332018v18n2a19.

MEGHWAL, P. R. et al. Micropropagation studies on guava. Indian Journal of Horticulture, v.67, p.55-58, 2010. Available from: <https://www.indianjournals.com/ijor.aspx?target=ijor:ij h\&volume $=67 \&$ issue $=4 \&$ article $=012 \&$ type $=p d f>. \quad$ Accessed: Aug. 14, 2020.

PEREIRA, J. C. G. et al. Growth of 'prata-ana' banana's microshoots clone gorutuba from synthetic seeds: substrates and BAP concentration. Revista Brasileira de Fruticultura, v.39, e-892, 2017. Available from: $\quad<$ http://dx.doi.org/10.1590/0100-29452017892>. Accessed: Oct. 22, 2019. doi: 10.1590/0100-29452017892.

PREROSTOVA, S. et al. Cytokinins: their impact on molecular and growth responses to drought stress and recovery in Arabidopsis. Frontiers in Plant Science, v.9, e655, 2018. Available from: $<$ https://doi.org/10.3389/fpls.2018.00655>. Accessed: Nov. 21, 2019. doi: 10.3389/fpls.2018.00655.

ROSA, G. G. et al. Propagation of Prunus spp. rootstocks by cutting: effects of genotype, branch developmental stage, and cutting type. Ceres, v.64, n.1, p.090-097, 2017. Available from: $<$ http://dx.doi.org/10.1590/0034-737x201764010013>. Accessed: Aug. 11, 2020. doi: 10.1590/0034-737x201764010013.

ROSSATO, M. et al. Embryogenic potential of the callus of gabirobeira, Campomanesia adamantium (Cambess) O. Berg. Acta Scientiarum. Biological Sciences, v.41, p.1-9, 2019. Available from: $\quad<$ http://dx.doi.org/10.4025/actascibiolsci.v41i1.46358>. Accessed: Aug. 01, 2020. doi: 10.4025/actascibiolsci.v41i1.46358.

ROSSATO, M. et al. MULTIPLICAÇÃO E ENRAIZAMENTO in vitro DE GABIROBEIRA. Plant Cell Culture \& Micropropagation, v.11, p.70-77, 2015. Available from: $<$ http:// pccm.ufla.br/index.php/PlantCellCultureMicropropagation/article/ view/11/5>. Accessed: Aug. 01, 2020.

TELEGINSKI, F. et al. Resgate vegetativo de Campomanesia xanthocarpa Mart. ex O. Berg POR ALPORQUIA. Ciência Florestal, v.28, p.820-826, 2018. Available from: <http://dx.doi. org/10.5902/1980509832100>. Accessed: Aug. 01, 2020. doi: $10.5902 / 1980509832100$.

TIBERTI, A. S. et al. Cold storage and treatment with plant growth regulators in rooting of root and stems cutting of raspberry. Ciência Rural, Santa Maria, v.45, p.1445-1450, 2015. Available from: $<$ https://doi.org/10.1590/0103-8478cr20131502>. Accessed: Aug. 05, 2020. doi: 10.1590/0103-8478cr20131502.

ZUNTINI, D. V. et al. Seed and peel essential oils obtained from Campomanesia adamantium fruit inhibit inflammatory and pain parameters in rodents. PloS one, v.12, e0157107. 2017. Available from: <https://doi.org/10.1371/journal.pone.0157107>. Accessed: Dec. 19, 2020. doi: 10.1371/journal.pone.0157107. 